\title{
MRS Addresses Visa Delays Inhibiting Scientific Progress in the United States
}

Among the approximately 13,000 scientists and engineers in the Materials Research Society working toward fundamental breakthroughs in electronics, aerospace, biomedical devices, nanotechnology, power systems, advanced computation and communication technologies, and many other fields of materials science, $35 \%$ are from outside the United States. This fraction has been growing at the rate of $1 \%$ per year for the last two decades. Currently, 30\%-40\% of the attendees at the MRS Spring and Fall Meetings come from outside the United States, and it is clear that non-U.S. scientists and engineers play an important and valued role in the Society at all levels, from presenting papers at our meetings to serving on committees, task forces, and the Board of Directors.

Well beyond their MRS activities, nonU.S. scientists, engineers, and students play a broad and important role in the advancement of science in the United States. However, the complicated interactions so critical to advances in fundamental materials research have been hindered by recently adopted visa practices intended to decrease the vulnerability of the United States to terrorism.

This article is written to inform both U.S. and non-U.S. members of MRS of the Society's concerns over these issues and what MRS is doing about them. We are distressed about the impact of current visa processes on our field, and the consequences for the associated billions of dollars of high-tech enterprise and national security capability that our field generates and supports.

This past summer, the MRS leadership sent a letter to George Atkinson, the science and technology advisor to U.S.

Secretary of State Colin Powell. We elaborated on the impact non-U.S. scientists and immigrants have made on materials research and the U.S. economy. Following are the statistics and sources furnished to the State Department, cast in terms meant to urge the department to take action and remedy the current obstacles to scientific communication and exploration within U.S. borders.

\section{We are distressed about the impact of current visa processes on our field.}

Due to continued diminishing support for physical sciences, mathematics, and engineering education in the United States-an unfortunate neglect that has accumulated over the course of 30 years $^{1-3}$ - the United States is now overwhelmingly dependent on non-U.S. scientists to contribute the breakthroughs that propel U.S. science forward. While the non-U.S.-born population makes up only $16.4 \%$ of physical scientists and engineers within the United States, ${ }^{4}$ it represents $55 \%$ of the $\mathrm{PhD}$-degree recipients in engineering from U.S. universities, $56 \%$ of the "hottest" papers in physical science and engineering fields, ${ }^{4}$ and $65 \%$ of the mostcited authors in those fields. ${ }^{4}$ Whether in Silicon Valley ${ }^{6}$ or in Austin, Texas, $725 \%$ of all U.S. technology start-ups are founded by immigrant entrepreneurs. ${ }^{6-7}$ In 1998, U.S. immigrants collectively accounted for more than $\$ 16.8$ billion in sales and over 58,000 jobs in Silicon Valley. ${ }^{6}$ Even the very young contribute: In 2004, 60\% of Intel Talent Search Winners (the "Junior Nobel Prize") were U.S. immigrants or the children of U.S. immigrants. ${ }^{8}$ Sixty-five percent of the U.S. 2004 Math Olympiad's top scorers and $46 \%$ of the U.S. Physics Team were immigrants or children of immigrants. ${ }^{8}$

Despite decades of inattention to cultivating domestic talent, the United States has prospered through the very selective importation of qualified individuals from abroad, using the U.S. university system as a filter for capturing some of the most talented students in the world. That filter has become clogged.

Prior to September 11, 2001, the rate of non-U.S. student enrollment at U.S. universities had been increasing by about $5 \%$ per year for the prior five years. ${ }^{9}$ By the 2002-2003 academic year, that rate of increase had dropped to $0.6 \% ;{ }^{9}$ by the 2003-2004 academic year, there was no increase. ${ }^{10}$ Right now, in the 2004-2005 academic year, we see a startling decline of $32 \%$ in non-U.S. student enrollment applications to U.S. universities, compared with last year, as reported by the Council of Graduate Schools. ${ }^{11}$

The effects of visa-related obstacles are felt even in nations with no direct connection to terrorism. Applications from European students to $30 \%$ of U.S. universities with the largest international student enrollments have declined. ${ }^{11}$ The Council of Graduate Schools attributes the overall decline to delays in the student visa process. ${ }^{11}$

While recognizing that U.S. security needs demand adequate screening of students entering the country, there are reasonable procedures that can address these needs while easing the visa process for students. For example, now that the Web-based Student and Exchange Visitor Information System (SEVIS) is in place to 
continuously track non-U.S. students while they are in the United States, there is little need to ask them to reapply for a visa each time they return home for a funeral, wedding, or other family event.

Furthermore, by nearly 2 to 1, Americans oppose suggestions that the country cut back on the number of non-U.S. students allowed to study in the United States. ${ }^{12}$ We let the State Department know about this survey. In our view, the U.S. public understands the international and scientific benefits that are the result and which have made our system thrive.

The visitor problem extends beyond student enrollment; high-level scientists from abroad experience unaccustomed and burdensome levels of scrutiny when they come to the United States as conference and meeting attendees. On January 5, 2004, the US-VISIT program went into effect, requiring most visitors to the United States to have their index fingerprints scanned and a digital photograph taken at their port of entry. As of October 26, 2004, travelers from all 27 Visa Waiver Program countries are required to present a machine-readable passport or a U.S. visa. We have been told, anecdotally, of scientists returning home from the United States and advising their students and colleagues not to go. The United States is developing a reputation for being unwelcoming to the highest level of skilled visitors and potential immigrants.

In contrast, the European Union's Sixth Framework Programme, operating from 2002 to 2006, has explicit provisions for capturing immigrant talent of the type currently being turned away by the United States. ${ }^{13}$ Australia, New Zealand, Germany, and Canada have all gone on record as developing immigration strategies with the primary aim of attracting foreign technical talent. ${ }^{14}$ The reason for this strategy among developed countries is obvious: The net present economic value of an immigrant with anything more than a high school education is $\$ 198,000$ - much more so for the technically trained. ${ }^{15}$ In nations that have aging workforces, there are few ways to support mounting entitlement spending on retirees other than to "capture" potential high-wage earners who can contribute more than their fair share to the future tax base and also to the general state of economic growth.

In our letter to the U.S. State Department, we emphasized how other nations may see the current U.S. position as a golden opportunity to capture the best and brightest global scientific talent. In order to reestablish the international "sharing" of this talent for the advancement of science, we suggested procedures that would ease the visa process for legitimate scientists while still addressing security needs, as follows.

Conference attendees would benefit from a visa that would allow multiple entries over a specified course of time. The scientific community has a very high proportion of repeat international visitors, and the cumulative effect of screening each one multiple times in a year no doubt burdens the visa system unduly for all other applicants. Furthermore, the requirement to reapply for a visa in one's home country (rather than the country of current residence) is a barrier to attendance at U.S.based conferences by other nations' students, diminishing the influx of knowledge to the United States. Reinstating the practice of allowing visa applications to be received at any U.S. consulate or embassy would greatly ameliorate this inconvenience for all visitors and its associated economic fallout. We are sure that the State Department can provide additional solutions to these vexing problems, and we offered assistance from the MRS leadership with any part of the process.

HOWARD E. KATZ 2004 MRS President MERRILEA J. MAYO 2003 MRS President DAVID J. EAGLESHAM 2004 Vice President and President-Elect

\section{References}

1. "Road Map for National Security: Imperative for Change," report of the United States Commission on National Security/21st Century (also called the Hart-Rudman report) (February 21, 2001) pp. 30-46.

2. "Assessing the U.S. R\&D Investment," report of the President's Council of Advisors on Science and Technology (PCAST) (October 16, 2002), available at Web site http://www. ostp.gov / PCAST / FINA L \% 20R\&D\%
20REPORT\%20WITH\%20LETTERS.pdf (accessed October 2004).

3. From 1970 to 2003, federal funding for the physical sciences and engineering declined from $0.25 \%$ to $0.16 \%$ of the U.S. gross domestic product (GDP).

4. S.G. Levi and P.E. Stephan, "Are the Foreign Born a Source of Strength for U.S. Science?" Science 285 (1999) p. 1213.

5. Science and Engineering Indicators 2004 (NSB 04-01) (National Science Board, Arlington, VA, 2004)

6. A. Saxenian, Silicon Valley's New Immigrant Entrepreneurs (Public Policy Institute, San Francisco, 1999).

7. John S. Butler, Chair of the Dept. of Management, Red McCombs School of Business, University of Texas, cited in the Austin American-Statesman, June 9, 2002.

8. S. Anderson, "The Multiplier Effect," International Educator (Summer 2004) p. 14

9. Institute of International Education Survey, summarized on Web site http://opendoors. iienetwork.org/? $\mathrm{p}=36525$ (accessed October 2004) and also in the Chronicle of Higher Education, November 7, 2003.

10. Philip Altbach, Christian Science Monitor, March 16, 2004.

11. Council of Graduate Schools enrollment survey, 2004. Results summarized at Web site h t t p : / / w w w.cgsnet.org/pdf / CGS_PR_IntlSurvey.pdf (accessed October 2004).

12. 2004 Opinion Dynamics Poll, commissioned by the Educational Testing Service. As summarized on Web site http://www.ets. org/aboutets/issues13.html (accessed October 2004)

13. Many provisions of the Sixth Framework encourage immigration through opportunities for third-country scientists; these range from research funding availability to aggressive fellowship programs. Details can be found at Web site www.essex.ac.uk/rbdo/ research/ UKRO_INCO.ppt (accessed October 2004) (one of many similar sites).

14. Mihir A. Desai, Devesh Kapur, and John McHale, "Sharing the Spoils: Taxing International Human Capital Flows," presented at the NBER-NCAER conference on India's Economic Reforms (December 2000), downloadable from Web site http://www.wcfia. harvard.edu/seminars/pegroup/Desai-KapurMchale.pdf (accessed October 2004).

15. The New Americans: Economic, Demographic, and Fiscal Effects of Immigration, National Research Council Panel on the Demographic and Economic Impacts of Immigration, edited by J.P. Smith and B. Edmonston (National Academy Press, Washington, DC, 1997).

FOR SCIENCE POLICY AFFECTING MATERIALS RESEARCH . . . ... access the Materials Research Society Web site: www.mrs.org/pa/ 